\title{
PENGARUH METODE PEMBELAJARAN DAN KOMUNIKASI INTERPERSONAL TERHADAP HASIL BELAJAR SISWA PADA MATA BIOLOGI
}

\author{
Dewi Aswida Br Sagala dan Hasan Saragih ${ }^{2}$ \\ SMK Negeri 2 Rantau Utaral dan Universitas Negeri Medan ${ }^{2}$ \\ dewiaswida@yahoo.com ${ }^{1}$ dan ahasansaragih@gmail.com ${ }^{2}$
}

\begin{abstract}
Abstrak: Penelitian ini bertujuan untuk mengetahui: (1) perbedaan hasil belajar biologi kelompok siswa yang menggunakan metode pembelajaran peta pikiran dengan narasi (2) perbedaan hasil belajar biologi siswa yang memiliki kemampuan interpersonal tinggi dengan interpersonal rendah. (3) interaksi antara penggunaan metode pembelajaran dengan kemampuan komunikasi interpersonal terhadap hasil belajar. Metode penelitian eksperimental-semu dengan desain faktorial 2x2. Teknik analisis deskriptif dengan statistik inferensial ANAVA dua jalur taraf signifikan $\alpha=0,05$ dilanjutkan dengan uji Scheffe. Hasil penelitian menunjukkan bahwa: (1) hasil belajar Biologi kelompok siswa yang diajar dengan metode pembelajaran peta pikiran lebih tinggi dibandingkan dengan kelompok siswa yang diajar dengan metode pembelajaran narasi $F_{\text {hitung }}=32,15>F_{\text {tabel }}=4,016$. (2) Hasil belajar siswa Biologi kelompok siswa yang memiliki komunikasi interpersonal tinggi lebih tinggi dibandingkan dengan kelompok siswa yang memiliki komunikasi interpersonal rendah $F_{\text {hitung }}=11,67>F_{\text {tabel }}=4,016$, dan (3) Terdapat interaksi antara metode pembelajaran dan komunikasi interpersonal terhadap hasil belajar Biologi $F_{\text {hitung }}=4,77$ > $F_{\text {tabel }}=4,02$ pada taraf signifikan $\alpha=0,05$.
\end{abstract}

Kata Kunci: metode pembelajaran, komunikasi interpersonal, biologi

Abstract: This study aims to determine: (1) differences in learning outcomes biology student group that uses the mind map learning method with narration (2) differences in the biology of learning outcomes of students who have high interpersonal skills with interpersonal low. (3) the interaction between learning method with the use of interpersonal communication skills to the learning outcomes. Quasi-experimental research methods with a $2 \times 2$ factorial design. Techniques descriptive inferential statistical analysis ANOVA two-lane significant level $\alpha=0.05$ followed by Scheffe test. The results showed that: (1) the results of studying Biology group of students who are taught by the teaching methods the mind map is higher than the group of students who are taught to narrative learning method of $F=32.15>F$ table $=4.016$. (2) The results of student learning Biology group of students who have high interpersonal communication is higher than the group of students who have low interpersonal communication of $F=11.67>F$ table $=4.016$, and (3) There are interactions between teaching methods and interpersonal communication on learning outcomes Biology Fhitung $=4.77>F$ table $=4.02$ at the significant level $\alpha=0.05$.

Keywords: methods of learning, interpersonal communication, biology

\section{PENDAHULUAN}

Mata diklat biologi merupakan salah satu mata diklat adaptif pada Bidang Studi Keahlian Agribisnis dan Agroteknologi di SMKN 2 Rantau Utara. Pada umumnya seluruh mata pelajaran di SMK lebih menekankan ranah psikomotorik dibandingkan dengan ranah kognitif, sehingga materi pembelajaran yang menekankan pemahaman konsep seperti mata diklat biologi kurang menarik minat siswa. Berdasarkan observasi awal yang dilakukan di SMKN 2 Rantau Utara diperoleh data bahwa siswa kurang menyukai mata diklat biologi. Dari data yang diperoleh dapat dilihat bahwa rata-rata nilai ulangan harian yang diperoleh oleh siswa masih kurang memuaskan karena banyak yang tidak memenuhi Kriteria Ketuntasan Minimal (KKM) pada mata diklat biologi yaitu 60. Hal ini disebabkan karena metode pembelajaran yang dilaksanakan oleh guru hanya metode ceramah saja, sehingga kurang menarik minat siswa untuk belajar. Fenomena ini akan berdampak pada penurunan kualitas hasil belajar yang diperoleh oleh siswa. Oleh karena itu, perlu dirancang metode pembelajaran yang sesuai dengan karakteristik siswa SMK untuk lebih meningkatkan minat belajar siswa. 
Masalah yang juga dihadapi oleh siswa SMKN 2 Rantau Utara selain nilai ulangan harian biologi yang rendah adalah dalam hal berkomunikasi. Hal ini dapat dilihat dari diskusi-diskusi yang dilaksanakan di dalam kelas. Pada umumnya diskusi tidak berlangsung seperti yang diharapkan. Siswa yang berdiskusi sebagian besar hanya diam saja dan tidak pernah mengeluarkan pendapat atau idenya sama sekali. Berdasarkan data awal yang diperoleh, hal ini disebabkan kurangnya keberanian siswa untuk mengeluarkan ide atau pendapatnya.

Mind map (peta pikiran) merupakan suatu teknik mencatat yang ditemukan oleh seorang pakar memori otak dari Inggris, yaitu Tony Buzan. Buzan (2008) mengemukakan bahwa mind map adalah cara termudah untuk menempatkan informasi ke dalam otak dan mengambil informasi ke luar dari otak. Mind map adalah cara mencatat yang kreatif, efektif, dan secara harfiah akan memetakan pikiran kita.

Menurut Sardiman (2009), dalam pengertian luas belajar dapat diartikan sebagai kegiatan psiko-fisik menuju ke perkembangan pribadi seutuhnya. Kemudian dalam arti sempit belajar dimaksudkan sebagai usaha penguasaan materi ilmu pengetahuan yang merupakan sebagian kegiatan menuju terbentuknya kepribadian seutuhnya. Dengan kata lain, belajar pada hakikatnya merupakan usaha yang dilakukan untuk memenuhi pengetahuan yang bertujuan untuk membentuk kepribadian dan jati diri manusia.

Selanjutnya Sardiman (2009) juga menyatakan bahwa secara umum belajar boleh dikatakan juga sebagai suatu proses interaksi antara diri manusia dengan lingkungannya yang mungkin berwujud pribadi, fakta, konsep ataupun teori. Slameto (2003) berpendapat bahwa belajar adalah suatu proses usaha yang dilakukan seeorang untuk memperoleh suatu perubahan tingkah laku yang baru secara keseluruhan, sebagai hasil pengalamannya sendiri dalam interaksi dengan lingkungannya. Perubahan itu ditunjukkan dengan berbagai bentuk seperti perubahan pengetahuan, sikap dan tingkah laku, kecakapan, keterampilan, dan lain-lain. Belajar pada dasarnya berbicara tentang seseorang yang berubah akibat pengalaman. Belajar menurut Syah (2005) adalah tahapan perubahan seluruh tingkah laku individu yang relatif menetap sebagai hasil pengalaman dan interaksi dengan lingkungan yang melibatkan proses kognitif.
Hasil belajar menurut Arikunto (2009) merupakan suatu hasil yang diperoleh siswa dalam mengikuti suatu proses pembelajaran yang dinyatakan dalam bentuk angka dan huruf. Sedangkan menurut Abdurrahman (2003) hasil belajar adalah kemampuan yang diperoleh anak setelah melalui kegiatan belajar.

Gagne dan Briggs dalam Hamid (2009) mengemukakan lima kemampuan sebagai hasil belajar, yaitu: 1) Informasi verbal, yaitu kemampuan untuk mengingat kembali suatu infomasi, 2) Keterampilan intelektual, yaitu kemampuan untuk mengorganisasi dan berinteraksi dengan lingkungan, 3) Strategi kognitif, yaitu kemampuan untuk mengembangakan cara-cara untuk meningkatkan keefektifan dan efisiensi proses berpikir dan proses belajarnya, 4) Sikap yaitu kemampuan untuk memilih melakukan tindakan yang sama untuk situasi sama yang berulang, dan 5) Keterampilan motorik, yaitu kemampuan untuk mengembangkan keterampilan motorik.

Menurut Bloom dalam Hamid (2009) menyatakan bahwa hasil pembelajaran yang menunjukkan proses perkembangan kemampuan dalam diri pebelajar dapat dikategorikan ke dalam tiga ranah, yakni kognitif, afektif dan psikomotorik. Kognitif adalah ranah yang menaruh perhatian pada pengembangan kemampuan dan keterampilan intelektual yang meliputi: pengetahuan, pemahaman, penerapan, analisis, sintesis, dan evaluasi. Afektif adalah ranah yang berkaitan dengan pengembangan perasaan, sikap, nilai dan emosi. Psikomotorik adalah ranah yang berkaitan dengan kegiatan-kegiatan manipulatif atau keterampilan motorik.

Romizowski (1981) mengemukakan bahwa hasil belajar seseorang diperoleh dalam bentuk pengetahuan dan keterampilan. Pengetahuan dikelompokkan dalam empat kategori, yaitu: fakta, prosedur, konsep dan prinsip. Fakta adalah pengetahuan tentang objek nyata yang merupakan asosiasi dari kenyataankenyataan dan informasi verbal. Konsep merupakan pengetahuan tentang serangkaian objek atau defenisi. Prosedur merupakan pengetahuan tentang tindakan demi tindakan yang bersifat linier dalam mencapai suatu tujuan. Prinsip merupakan pernyataan hubungan antara dua konsep atau lebih yang bersifat kasual, korelasional dan sebagainya. Menurut Ausubel (1963) struktur kognitif merupakan faktor utama yang berpengaruh terhadap proses belajar dan retensi materi baru. Berdasarkan struktur kognitif, pengetahuan 
diorganisasi secara hirarkhis, dimana pengetahuan yang lebih umum, inklusif dan abstrak membawahi pengetahuan baru yang lebih spesifik dan konkrit.

Berdasarkan beberapa definisi diatas dapat disimpulkan bahwa pengertian belajar adalah suatu proses perubahan tingkah laku baik secara kualitas maupun kuantitas yang dipengaruhi dan diperkuat oleh lingkungan yang bersifat permanen sebagai akibat dari latihan. Proses perubahan yang terjadi terdapat dalam ruang lingkup ranah kognitif, afektif, dan psikomotorik.

Menurut Mulyasa dalam Herlina (2007), belajar biologi merupakan wahana untuk menyadari keteraturan alam untuk mengagungkan kebesaran dan kekuasaan Tuhan Yang Maha Esa. Wahyudi (2007) menjelaskan bahwa hakikat hasil belajar biologi adalah untuk menghantarkan siswa menguasai konsepkonsep IPA dan keterkaitannya untuk dapat memecahkan masalah dalam kehidupan seharihari. Kata menguasai mengisyaratkan bahwa harus menjadikan siswa tidak sekedar tahu dan hafal tentang konsep-konsep IPA, melainkan harus menjadikan siswa untuk mengerti dan memahami konsep-konsep tersebut dan menghubungkan keterkaitan suatu konsep dengan konsep lain.

Reigeluth (1983) berpendapat bahwa tiga komponen utama pembelajaran, yaitu: kondisi pembelajaran, metode pembelajaran dan hasil pembelajaran. Kondisi pembelajaran adalah faktor-faktor yang mempengaruhi efek metode dalam meningkatkan hasil pembelajaran. Metode pembelajaran adalah cara-cara yang berbeda untuk mencapai hasil pembelajaran yang berbeda di bawah kondisi yang berbeda. Hasil pembelajaran adalah semua efek yang dapat dijadikan sebagai indikator tentang nilai dari penggunaan metode pembelajaran di bawah kondisi yang berbeda.

Merrill (1991) mengemukakan bahwa dalam proses pembelajaran seorang guru berperan sebagai mediator dan fasilitator yang membantu agar proses pembelajaran berjalan dengan baik. Menurut Gerlach dan Ely dalam Uno (2007) teknik pembelajaran seringkali disamakan artinya dengan metode pembelajaran. Teknik adalah jalan, alat, atau media yang digunakan oleh guru untuk mengarahkan kegiatan peserta didik ke arah tujuan yang ingin dicapai.

$$
\text { Selanjutnya }
$$

Uno

mengemukakan bahwa metode pembelajaran didefinisikan sebagai cara yang digunakan guru yang dalam menjalankan fungsinya merupakan alat untuk mencapai tujuan pembelajaran. Metode pembelajaran lebih bersifat prosedural, yaitu berisi tahapan tertentu, sedangkan teknik adalah cara yang digunakan yang bersifat implementatif. Dengan perkataan lain, metode yang dipilih oleh masing-masing guru adalah sama, tetapi mereka menggunakan teknik yang berbeda.

Suparman (2001) mengemukakan bahwa metode pembelajaran berfungsi sebagai cara dalam menyajikan (menguraikan, memberi contoh, dan memberi latihan) isi pelajaran kepada mahasiswa untuk mencapai tujuan tertentu. Menurut Sitorus dan Mardianto (2005) metode pembelajaran adalah bagian dari satu strategi pembelajaran, dimana satu strategi pembelajaran tertentu dapat dikembangkan dalam beberapa metode. Metode itu sendiri dapat dijabarkan dalam beberapa teknik pembelajaran. Hubungan antara strategi, tujuan, dan metode pembelajaran dapat digambarkan sebagai suatu kesatuan sistem yang bertitik tolak dari penentuan tujuan pembelajaran, pemilihan strategi pembelajaran, dan perumusan tujuan yang kemudian diimplementasikan ke dalam berbagai metode yang relevan selama proses pembelajaran berlangsung (Uno, 2007).

Mind map (peta pikiran) merupakan suatu teknik mencatat yang ditemukan oleh seorang pakar memori otak dari Inggris yaitu Tony Buzan. Buzan (2008) mengemukakan bahwa mind map adalah cara termudah untuk menempatkan informasi ke dalam otak dan mengambil informasi keluar dari otak. Mind map adalah cara mencatat yang kreatif, efektif, dan secara harfiah akan memetakan pikiran kita. Mind map adalah cara yang mudah untuk membangkitkan imajinasi dan membantu kita mengingat. Hal ini disebabkan mind map melibatkan sisi kanan otak secara alami melalui penggunaan warna dan gambar. Mind map mendorong otak untuk membuat asosiasi. Setiap cabang mengaitkan satu pikiran dengan pikiran lainnya. Mind map juga merupakan cara kreatif untuk mengatur informasi ke dalam kelompok pada sebuah halaman dan menggunakan gambar-gambar sebagai simbol pemicu.

DePorter dan Hernacki (2002) menjelaskan bahwa peta pikiran adalah suatu teknik mencatat yang memanfaatkan keseluruhan otak dengan menggunakan citra visual dan prasarana grafis lainnya untuk membentuk kesan. Detail-detail dari suatu peta 
pikiran mudah diingat karena mengikuti pola pemikiran otak. Peta pikiran memadukan dan mengembangkan potensi kerja otak yang terdapat di dalam diri seseorang. Dengan adanya keterlibatan kedua belahan otak maka akan memudahkan seserorang untuk mengingat informasi dalam bentuk gambar, simbol, suara, bentuk-bentuk, dan perasaan. Peta pikiran menggunakan pengingat-pengingat visual dan sensorik dalam suatu pola dari ide-ide yang berkaitan. Peta pikiran dapat membangkitkan ide-ide orisinal dan memicu ingatan yang mudah

Mencatat merupakan salah satu usaha untuk meningkatkan daya ingat. Otak manusia dapat menyimpan segala sesuatu yang dilihat, didengar dan dirasakan. Peta pikiran merupakan bentuk catatan yang tidak monoton karena mind map melibatkan kedua sisi otak yang menggunakan gambar, warna, dan imajinasi bersamaan dengan kata, angka, dan logika. Mind map juga menodorong pemikiran sinergis. Peta pikiran juga mendorong kita untuk menciptakan lebih banyak ide dari setiap pikiran kita. Mind map membantu otak membuat lompatan pengertian dan imajinasi besar melalui asosiasi. Mind map membantu kita menguatkan peta-peta pikiran di dalam otak. Mind map menyerupai bentuk pola-pola pikir kita, maka tindakan menggambarkannya adalah pengulangan yang alami dan mudah diingat (Buzan, 2008).

Menurut DePorter dan Hernacki (2002), metode mencatat yang baik dan efektif harus membantu kita untuk mengingat detaildetail tentang poin-poin kunci, memahami konsep-konsep utama, dan melihat kaitannya. Proses pembelajaran seharusnya dapat menggunakan teknik mind map sebagai salah satu cara belajar yang dapat dilatihkan kepada siswa. Penggunaan teknik meringkas catatan dengan mind map dalam pebelajaran diharapkan dapat meningkatkan hasil belajar dan kreatifitas mahasiswa. Belajar berbasis mind map didefenisikan sebagai semua perubahan pada kapabilitas dan perilaku organisme, baik secara mental maupun fisik yang diakibatkan oleh pengalaman. Terdapat banyak tambahan yang dapat diperoleh melalui penerapan mind map. Teknik meringkas catatan menggunakan mind map akan membuat ide tercurah dengan membiarkannya mengalir dari satu ide lalu memancarkannya ke ide berikutnya (Olivia, 2008). Umumnya siswa membuat catatan konvensional dalam bentuk tulisan linier panjang yang mencakup seluruh isi materi pelajaran, sehingga catatan terlihat sangat monoton dan membosankan. Umumnya catatan monoton akan menghilangkan topik-topik utama yang penting dari materi pelajaran.

Buzan (2008) juga menyatakan bahwa kelebihan mind map adalah sebagai berikut: a) Memberi pandangan menyeluruh pokok masalah atau area yang luas, b) Memungkinkan kita merencanakan rute atau membuat pilihanpilihan dan mengetahui kemana kita akan pergi dan dimana kita berada, c) Mengumpulkan sejumlah besar data di satu tempat, d) Mendorong pemecahan masalah dengan membiarkan kita melihat jalan-jalan terobosan kreatif baru, e) Menyenangkan untuk dilihat, dibaca, dicerna, dan diingat.

Peta pikiran adalah teknik meringkas bahan yang akan dipelajari dan memproyeksikan masalah yang dihadapi ke dalam bentuk peta atau teknik grafis sehingga lebih mudah memahaminya (Sugiarto, 2004). Menurut Mahmuddin (2009) mind map adalah satu teknik meringkas catatan yang mengembangkan gaya belajar visual. Mind map memadukan dan mengembangkan potensi kerja otak yang terdapat di dalam diri seseorang. Dengan adanya keterlibatan kedua belahan otak, maka akan memudahkan seseorang untuk mengatur dan mengingat segala bentuk informasi, baik secara tertulis maupun secara verbal. Adanya kombinasi warna, simbol, bentuk, dan sebagainya memudahkan otak dalam menyerap informasi yang diterima.

Pembelajaran tidak hanya terbatas pada membaca buku atau mendengar pembelajaran saja. Menurut Yovan dalam Mahmuddin (2009), pembelajaran melibatkan pemikiran yang bekerja secara asosiasi, sehingga dalam setiap pembelajaran terjadi penghubungan antar satu informasi dengan informasi yang lain. Pembelajaran sangat erat kaitannya dengan penggunaan otak sebagai pusat aktifitas mental mulai dari pengambilan, pemrosesan, hingga penyimpulan informasi. Dengan demikian, pembelajaran merupakan proses sinergisme antara otak, pikiran dan pemikiran untuk menghasilkan daya guna yang optimal.

Selanjutnya menurut Yovan dalam Mahmuddin (2009) keutamaan teknik meringkas catatan menggunakan mind map antara lain: (1) Tema utama terdefenisi secara sangat jelas karena dinyatakan di tengah, (2) Level keutamaan informasi teridentifikasi secara lebih baik. Informasi yang memiliki kadar kepentingan lebih diletakkan dengan tema utama, (3) Hubungan masing-masing 
informasi secara mudah dapat segera dikenali, (4) Lebih mudah dipahami dan diingat, (5) Informasi baru setelahnya dapat segera digabungkan tanpa merusak keseluruhan struktur mind map sehingga mempermudah proses pengingatan, dan (7) Mempercepat proses pencatatan karena hanya menggunakan kata kunci.

Johan dalam Mahmuddin (2009) menjelaskan bahwa mind map merupakan suatu tekni grafik yang sangat ampuh dan menjadi kunci yang universal untuk membuka potensi dari seluruh otak, karena menggunakan seluruh keterampilan yang terdapat pada bagian neo korteks dari otak atau yang lebih dikenal sebagai otak kiri dan otak kanan. Mind map mampu memangkas waktu belajar dengan mengubah pola pencatatan linear yang memakan waktu menjadi pencatatan yang efektif yang sekaligus langsung dapat dipahami oleh individu.

Menurut Enre (1988) narasi adalah salahsatu bentuk wacana yang secara umum merupakan pernyataan pikiran dan perasaan baik mengenai benda atau keadaan yang nyata ataupun yang diharapkan dengan menggunakan bahasa tulis sebagai alatnya. Wacana atau narasi menuntut penyajian yang cermat, teratur, dan jelas agar apa yang dimaksud oleh penulis tidak salah difahami oleh pembaca.

Narasi merupakan salah satu bentuk tulisan yang diterapkan dalam proses pembelajaran. Keraf (1994) mengungkapkan bahwa narasi dapat dibatasi sebagai suatu bentuk wacana yang sasaran utamanya adalah tindak tanduk yang dijalin dan dirangkaikan menjadi sebuah peristiwa yang terjadi dalam suatu waktu.

Menurut Semi (1990) narasi merupakan bentuk percakapan atau tulisan yang bertujuan menyampaikan atau menceritakan rangkaian peristiwa atau pengalaman manusia berdasarkan perkembangan dari waktu ke waktu. Narasi adalah suatu bentuk wacana yang berusaha menggambarkan dengan sejelas-jelasnya kepada pembaca suatu peristiwa yang telah terjadi berdasarkan urutan waktu. Hal ini berarti bahwa dalam menulis narasi yang perlu menjadi perhatian utama adalah urutan waktu dari sebuah wacana tersebut.

Menurut Lewis (1987) komunikasi adalah pertukaran pesan yang menghasilkan pembagian makna antara pengirim dan penerima pesan. Proses seperti ini berlangsung dalam seluruh dimensi pergaulan manusia baik dalam konteks kehidupan sosial maupun dalam suatu organisasi tertentu.

Robins (1984) menjelaskan substansi dari komunikasi adalah pengiriman dan pemahaman terhadap makna. Sedangkan komunikasi yang baik itu adalah bila makna yang dikirimkan oleh pengirim pesan dimengerti secara tepat oleh penerima pesan.

Komunikasi interpersonal adalah suatu proses pertukaran makna antara orang-orang yang saling berkomunikasi. Pengertian proses mengacu pada perubahan dan tindakan yang berlangsung secara terus menerus. Pengertian pertukaran yaitu tindakan menyampaikan dan menerima pesan secara timbal balik. Makna yaitu sesuatu yang dipertukarkan dalam proses tersebut (Komala, 2009). Menurut Mulyana (2007), komunikasi interpersonal adalah komunikasi antara orang-orang secara tatap muka, yang memungkinkan setiap pesertanya menangkap reaksi orang lain secara langsung, baik secara verbal maupun non-verbal.

Devito dalam Thoha

menjelaskan bahwa komunikasi interpersonal adalah proses penyapaian berita yang dilakukan seseorang dan diterimanya berita tersebut oleh orang lain atau kelompok kecil dari orang-orang dengan suatu akibat dan umpan balik segera. Selanjutnya Devito dalam Thoha (2003) menjelaskan bahwa komunikasi interpersonal akan efektif apabila memenuhi aspek-aspek berikut: (1) Keterbukaan, (2) Empati, (3) Dukungan, (4) Kepositifan, dan (5) Kesamaan. Keterbukaan adalah aspek dari komunikasi interpersonal yang menunjukkan keinginan untuk terbuka bagi setiap orang yang berinteraksi dengan orang lain. Empati adalah aspek dari komunikasi interpersonal yang berkaitan dengan merasakan sebagaimana yang dirasakan oleh orang lain yakni mencoba merasakan dalam cara yang sama dengan orang lain. Kita dapat mengkomunikasikan empati secara verbal dan non-verbal. Dukungan adalah aspek dari komunikasi interpersonal yang berkaitan dengan pemberian dukungan yang berbentuk ucapan maupun gerakan. Kepositifan adalah aspek dari komunikasi interpersonal yang berkaitan dengan perhatian yang positif terhadap diri seseorang. Kesamaan adalah aspek dari komunikasi interpersonal yang menyatakan bahwa pada hakekatnya manusia tidak ada yang sama sekalipun kembar dapat dilihat perbedaannya. Oleh karena itu, komunikasi interpersonal akan efektif apabila individuindividu yang berkomunikasi itu dalam suasana kesamaan. 
Menurut Roestiyah dan Suharto (1995) ada tiga kemampuan esensial yang harus dimiliki oleh setiap guru dalam proses pembelajaran, yaitu: (1) Kemampuan merencanakan kegiatan, (2) Kemampuan melaksanakan kegiatan, (3) kemampuan mengadakan komunikasi. Ketiga kemampuan itu sama pentingnya karena setiap guru tidak hanya mampu merencanakan kegiatan yang akan dikomunikasikan dan mampu melaksanakan kegiatan sesuai dengan rancangan, tetapi dia juga harus terampil dalam menciptakan iklim yang komunikatif dalam kegiatan pembelajaran.

$$
\text { Menurut Muhammad }
$$

(2007)

komunikasi interpersonal adalah proses pertukaran informasi diantara seseorang dengan paling tidak seorang lainnya atau biasanya diantara dua orang yang dapat langsung diketahui balikannya. Komunikasi interpersonal membentuk hubungan dengan orang lain. Selanjutnya Muhammad (2007) juga menjelaskan bahwa dalam komunikasi interpersonal terdapat beberapa prinsip umum, yaitu: (1) Komunikasi tidak dapat dielakkan, (2) Komunikasi tidak dapat dibalikkan, (3) Komunikasi mempunyai isi dan dimensi hubungan, (4) Komunikasi meliputi proses penyesuaian, 6) Interaksi mungkin dipandang sebagai sesuatu yang simetris. Muhammad (2007) juga menjelaskan tujuan komunikasi interpersonal antara lain: (1) Menemukan diri sendiri, (2) Menemukan dunia luar, (3) Membentuk dan menjaga hubungan yang penuh arti, (4) Berubah sikap dan tingkah laku, (5) Untuk bermain dan kesenangan, dan (6) Untuk membantu.

Roger dalam Muhammad (2007) menjelaskan bahwa komunikasi interpersonal akan berjalan efektif apabila kedua pihak yang berkomunikasi memenuhi kondisi berikut: (1) bertemu satu sama lain secara personal, (2) Empati secara tepat terhadap pribadi yang lain dan berkomunikasi yang dapat dipahami satu sama lain secara berarti, (3) Menghargai satu sama lain, bersifat positif dan wajar tanpa menilai atau keberatan, (4) Menghayati pengalaman satu sama lain dengan sungguhsungguh, bersikap menerima dan empati satu sama lain, (5) Merasa bahwa saling menjaga keterbukaan dan iklim yang mendukung dan mengurangi kecenderungan gangguan arti, dan (6) Memperlihatkan tingkah laku yang percaya penuh dan memperkuat perasaan aman terhadap yang lain.
Rahmat (2001) menjelaskan ada tiga faktor utama yang dapat menumbuhkan sikap percaya atau mengembangkan komunikasi interpersonal yaitu: pertama, menerima adalah kemampuan berhubungan dengan orang lain tanpa menilai dan tanpa berusaha mengendalikan dan juga menerima berkaitan dengan sikap melihat orang lain sebagai manusia dan sebagai individu yang patut dihargai. Kedua, empati adalah memahami orang lain yang tidak mempunyai arti emosional bagi kita. Dalam berempati, individu menempatkan diri secara imajinatif pada posisi orang lain. Ketiga, kejujuran adalah faktor yang menumbuhkan sikap percaya dalam komunikasi interpersonal.

Beberapa penelitian yang relevan dengan penelitian yang akan dilakukan dalam penelitian ini antara lain: (a) Hasil penelitian yang dilakukan oleh Samsul Kamal (2010) melihat pengaruh yang positif dalam meningkatkan hasil belajar siswa pada pembelajaran biologi dengan menggunakan mind map, (b) Hasil penelitian yang dilakukan oleh Supini (2010) menyatakan bahwa hasil belajar biologi siswa mengalami peningkatan dengan pembelajaran peta pikiran, (c) Hasil penelitian yang dilakukan oleh Nursamsu (2010) mengemukakan bahwa terdapat pengaruh yang positif antara strategi pembelajaran advance organizer dan peta pikiran terhadap hasil belajar biologi siswa, (d) Hasil penelitian yang dilakukan oleh Asnidawati (2010) menyatakan bahwa penggunaan peta pikiran dapat meningkatkan hasil belajar akuntasi siswa.

Masalah dalam penelitian ini dapat dirumuskan sebagai berikut: (1) Apakah terdapat perbedaan hasil belajar biologi kelompok siswa yang menggunakan metode pembelajaran peta pikiran dengan kelompok siswa yang menggunakan narasi?; (2) Apakah terdapat perbedaan hasil belajar biologi siswa yang memiliki kemampuan komunikasi interpersonal tinggi dengan siswa yang memiliki kemampuan komunikasi interpersonal rendah?; dan (3) Apakah terdapat interaksi antara penggunaan metode pembelajaran dengan kemampuan komunikasi interpersonal terhadap hasil belajar biologi siswa?

\section{METODE}

Penelitian ini dilaksanakan di SMK Negeri 2 Rantau Utara, Jl. W.R. Supratman No. 01 A, Kecamatan Rantau Utara, Kabupaten Labuhanbatu. Populasi pada penelitian ini 
adalah seluruh siswa kelas XI TPHP dan kelas XI APKJT di SMK Negeri 2 Rantau Utara dengan jumlah siswa 60 orang, yang terdiri dari kelas XI TPHP sebanyak 30 Orang dan kelas XI APKJT sebanyak 30 orang.

Teknik pengambilan sampel yang digunakan adalah teknik purposive sampling (sampel bertujuan) yang dilakukan dengan cara mengambil subyek bukan berdasarkan strata, random ataupun daerah, tetapi didasarkan atas tujuan tertentu. Sampel penelitian ini yang diambil terdiri dari dua kelompok, yaitu kelas XI TPHP yang berjumlah 30 orang di beri perlakuan dengan penggunaan metode pembelajaran peta pikiran dan kelas XI APKJT yang berjumlah 30 orang diberi perlakuan dengan penggunaan narasi, sehingga jumlah sampel dalam penelitian ini sebanyak 60 orang. Sebelum diberikan perlakuan, terlebih dahulu diberikan tes kemampuan komunikasi interpersonal, untuk mengklasifikasikan siswa yang termasuk ke dalam kelompok komunikasi interpersonal tinggi dan rendah.

Rancangan penelitian yang digunakan dalam penelitian ini adalah desain eksperimental dengan faktorial $2 \mathrm{X} 2$.

Tabel 1. Desain eksperimental dengan faktorial $2 X 2$

\begin{tabular}{|c|c|c|}
\hline $\begin{array}{ll}\text { Interpersonal } & \text { Metode Pembelajaran } \\
\end{array}$ & $\begin{array}{l}\text { Peta pikiran } \\
\left(\mathrm{A}_{1}\right)\end{array}$ & $\begin{array}{l}\text { Narasi } \\
\left(\mathrm{A}_{2}\right)\end{array}$ \\
\hline Tinggi $\left(\mathrm{B}_{1}\right)$ & $\mu \mathrm{A}_{1} \mathrm{~B}_{1}$ & $\mu \mathrm{A}_{2} \mathrm{~B}_{1}$ \\
\hline Rendah $\left(B_{2}\right)$ & $\mu \mathrm{A}_{1} \mathrm{~B}_{2}$ & $\mu \mathrm{A}_{2} \mathrm{~B}_{2}$ \\
\hline
\end{tabular}

Keterangan :

$\mu \mathrm{A}_{1} \mathrm{~B}_{1}$ : Hasil belajar siswa dengan menggunakan metode pembelajaran peta pikiran dengan kemampuan komunikasi interpersonal tinggi

$\mu \mathrm{A}_{1} \mathrm{~B}_{2}$ : Hasil belajar siswa dengan menggunakan metode pembelajaran peta pikiran dengan kemampuan komunikasi interpersonal rendah

$\mu \mathrm{A}_{2} \mathrm{~B}_{1}$ : Hasil belajar siswa dengan menggunakan narasi dengan kemampuan komunikasi interpersonal tinggi

$\mu \mathrm{A}_{2} \mathrm{~B}_{2}$ : Hasil belajar siswa dengan menggunakan narasi dengan kemampuan komunikasi interpersonal rendah

Teknik analisis data yang digunakan dalam penelitian ini adalah teknik statistik deskriptif dan inferensial. Teknik statistik deskriptif digunakan untuk mendeskripsikan data penelitian dengan daftar distribusi frekuensi dan membuat histogram. Dari data tersebut selanjutnya di hitung mean, median, modus dan standar deviasi. Teknik statistik inferensial digunakan untuk menguji hipotesis penelitian dengan teknik ANAVA dua jalur dengan desain faktorial 2X2 dan taraf signifikansi 0.05. Sebelum menggunakan ANAVA terlebih dahulu dilakukan persyaratan analisis yang meliputi uji normalitas dengan teknik Liliefors dan uji homogenitas varians dengan teknik Barlett. Apabila terdapat interaksi yang signifikan antara penggunaan teknik meringkas catatan dengan kemampuan komunikasi interpersonal, maka analisis dilanjutkan dengan uji Scheffe.

Pengujian hipotesis yang digunakan adalah analisis varians (ANAVA) dua jalur dengan taraf signifikansi $\alpha=0.05$. Untuk rumusan hipotesis statistik dinyatakan sebagai berikut :

Hipotesis 1 : Ho: $\mu \mathrm{A}_{1} \leq \mu \mathrm{A}_{2}$ $\mathrm{Ha}: \mu \mathrm{A}_{1}>\mu \mathrm{A}_{2}$

Hipotesis 2 ; Ho: $\mu \mathrm{B}_{1} \leq \mu \mathrm{B}_{2}$ $\mathrm{Ha}: \mu \mathrm{B}_{1}>\mu \mathrm{B}_{2}$

Hipotesis 3: Ho : Interaksi $A \rtimes B=0$

$\mathrm{Ha}$ : Interaksi $\mathrm{A}>\mathrm{B} \neq 0$

\section{HASIL DAN PEMBAHASAN \\ Hasil}

Populasi pada penelitian ini adalah seluruh siswa kelas XI TPHP dan kelas XI APKJT di SMK Negeri 2 Rantau Utara dengan jumlah siswa 60 orang, yang terdiri dari kelas XI TPHP sebanyak 30 Orang dan kelas XI APKJT sebanyak 30 orang. Sampel penelitian ini yang diambil terdiri dari dua kelompok, yaitu kelas XI TPHP yang berjumlah 30 orang di beri perlakuan dengan penggunaan metode pembelajaran peta pikiran dan kelas XI APKJT yang berjumlah 30 orang diberi perlakuan dengan penggunaan narasi. Data hasil penelitian dideskripsikan pada Tabel 2 berikut. 
Tabel 2. Tampilan Data Hasil Penelitian

\begin{tabular}{|c|c|c|c|c|c|c|c|}
\hline & \multicolumn{5}{|c|}{ Metode Pembelajaran } & \multirow{2}{*}{\multicolumn{2}{|c|}{ Total }} \\
\hline & & Pet: & kiran & & & & \\
\hline \multirow{6}{*}{$\begin{array}{l}\text { Komunikasi } \\
\text { Interpersonal }\end{array}$} & \multirow{3}{*}{ Tinggi } & $\mathrm{n}_{\mathrm{A} 1}$ & 15 & $\mathrm{n}_{\mathrm{A} 2}$ & 14 & $\mathrm{n}_{\mathrm{A}}$ & 29 \\
\hline & & $\mathrm{T}_{\mathrm{A} 1}$ & 332 & $\mathrm{~T}_{\mathrm{A} 2}$ & 270 & $\mathrm{~T}_{\mathrm{A}}$ & 602 \\
\hline & & $\bar{X}_{\mathrm{A} 1}$ & 22,13 & $\bar{X}_{\mathrm{A} 1}$ & 19,29 & $\overline{X_{A}}$ & 20,76 \\
\hline & \multirow{3}{*}{ Rendah } & $\mathrm{n}_{\mathrm{B} 1}$ & 15 & $\mathrm{n}_{\mathrm{B} 2}$ & 16 & $\mathrm{n}_{\mathrm{B}}$ & 31 \\
\hline & & $\mathrm{T}_{\mathrm{B} 1}$ & 261 & $\mathrm{~T}_{\mathrm{B} 2}$ & 253 & $\mathrm{~T}_{\mathrm{B}}$ & 514 \\
\hline & & $\bar{X}_{\mathrm{B} 1}$ & 17,4 & $\bar{X}_{\mathrm{B} 2}$ & 15,81 & $\bar{X} n_{B}$ & 16,58 \\
\hline \multirow{3}{*}{\multicolumn{2}{|c|}{ Total }} & $\mathrm{n}_{1}$ & 30 & $\mathrm{n}_{2}$ & 30 & $\mathrm{~N}$ & 60 \\
\hline & & $\mathrm{T}_{1}$ & 593 & $\mathrm{~T}_{2}$ & 523 & $\mathrm{~T}$ & 1116 \\
\hline & & $\overline{\mathrm{X}_{1}}$ & 19,77 & $\overline{\mathrm{X}_{2}}$ & 17,43 & $\bar{X}$ & 18,6 \\
\hline
\end{tabular}

\section{Pengujian Hipotesis}

Pengujian pasangan hipotesis statistik sesuai dengan teknik analisis data dengan menggunakan ANAVA factorial 2x2. Analisis varians (ANAVA) dua jalur adalah teknik pengujian hipotesis pada desain eksperimen untuk melihat interaksi antara variabel baris dan variabel kolom sesuai dengan desain yang digunakan dalam penelitian ini, maka data hasil belajar siswa dapat dilihat pada Tabel 3 berikut.

Tabel 3. Analisis Varians untuk Data Induk Penelitian

\begin{tabular}{|c|c|c|c|c|c|}
\hline Sumber Varians & $\mathrm{dk}$ & $\mathrm{Jk}$ & $\mathrm{RJk}$ & $\mathrm{F}_{\mathrm{h}}$ & $\mathrm{F}_{\mathrm{t}}$ \\
\hline Antar baris & 1 & 225,54 & 225,54 & 32,15 & 4,016 \\
\hline Antar kolom & 1 & 81,67 & 81,67 & 11,67 & 4,016 \\
\hline Interaksi & 1 & 33,44 & 33,44 & 4,77 & 4,016 \\
\hline Dalam kelompok & 56 & 392,63 & 7,01 & - & - \\
\hline
\end{tabular}

Karena terdapat interaksi antara metode pembelajaaran dan komunikasi interpersonal dalam mempengaruhi hasil belajar Biologi, maka perlu dilakukan uji lanjutan (post hoc test), untuk mengetahui rata-rata hasil belajar sampel yang berbeda. Untuk melihat bentuk interaksi tersebut dalam mempengaruhi hasil belajar Biologi dilakukan uji lanjut dengan menggunakan uji Scheffe. Dari hasil uji Scheffe diperoleh hasil yang dapat dilihat dalam Tabel 4. berikut.

Tabel 4. Ringkasan Hasil Perhitungan Uji Scheffe

\begin{tabular}{|c|c|c|c|c|c|}
\hline \multirow{2}{*}{ No } & \multicolumn{2}{|c|}{ Hipotesis Statistik } & $\mathrm{F}_{\text {hitung }}$ & $\begin{array}{c}\mathrm{F}_{\mathrm{t}(3,56)} \\
\mathrm{A}=5 \%\end{array}$ & Keterangan \\
\hline 1 & $\mathrm{H}_{\mathrm{o}}: \mu_{\mathrm{A} 1 \mathrm{~B} 1}=\mu_{\mathrm{A} 1 \mathrm{~B} 2}$ & $\mathrm{H}_{\mathrm{a}}: \mu_{\mathrm{A} 1 \mathrm{~B} 1}>\mu_{\mathrm{A} 1 \mathrm{~B} 2}$ & 22,37 & 4,16 & Signifikan \\
\hline 2 & $\mathrm{H}_{\mathrm{o}}: \mu_{\mathrm{A} 1 \mathrm{~B} 1}=\mu_{\mathrm{A} 2 \mathrm{~B} 1}$ & $\mathrm{H}_{\mathrm{a}}: \mu_{\mathrm{A} 1 \mathrm{~B} 1}>\mu_{\mathrm{A} 2 \mathrm{~B} 1}$ & 184,71 & 4,16 & Signifikan \\
\hline 3 & $\mathrm{H}_{\mathrm{o}}: \mu_{\mathrm{A} 2 \mathrm{~B} 1}=\mu_{\mathrm{A} 2 \mathrm{~B} 2}$ & $\mathrm{H}_{\mathrm{a}}: \mu_{\mathrm{A} 2 \mathrm{~B} 1}>\mu_{\mathrm{A} 2 \mathrm{~B} 2}$ & 138,83 & 4,16 & Signifikan \\
\hline 4 & $\mathrm{H}_{\mathrm{o}}: \mu_{\mathrm{A} 1 \mathrm{~B} 2}=\mu_{\mathrm{A} 2 \mathrm{~B} 2}$ & $\mathrm{H}_{\mathrm{a}}: \mu_{\mathrm{A} 1 \mathrm{~B} 2}>\mu_{\mathrm{A} 2 \mathrm{~B} 2}$ & 72,93 & 4,16 & Signifikan \\
\hline 5 & $\mathrm{H}_{\mathrm{o}}: \mu_{\mathrm{A} 1 \mathrm{~B} 2}=\mu_{\mathrm{A} 2 \mathrm{~B} 1}$ & $\mathrm{H}_{\mathrm{a}}: \mu_{\mathrm{A} 1 \mathrm{~B} 2}>\mu_{\mathrm{A} 2 \mathrm{~B} 1}$ & 70,99 & 4,16 & Signifikan \\
\hline 6 & $\mathrm{H}_{\mathrm{o}}: \mu_{\mathrm{A} 1 \mathrm{~B} 1}=\mu_{\mathrm{A} 2 \mathrm{~B} 2}$ & $\mathrm{H}_{\mathrm{a}}: \mu_{\mathrm{A} 1 \mathrm{~B} 1}>\mu_{\mathrm{A} 2 \mathrm{~B} 2}$ & 535,06 & 4,16 & Signifikan \\
\hline
\end{tabular}

Dari hasil pengujian hipotesis tersebut maka interaksi antara metode pembelajaran dan komunikasi interpersonal siswa dapat ditunjukkan pada Gambar 1 berikut. 


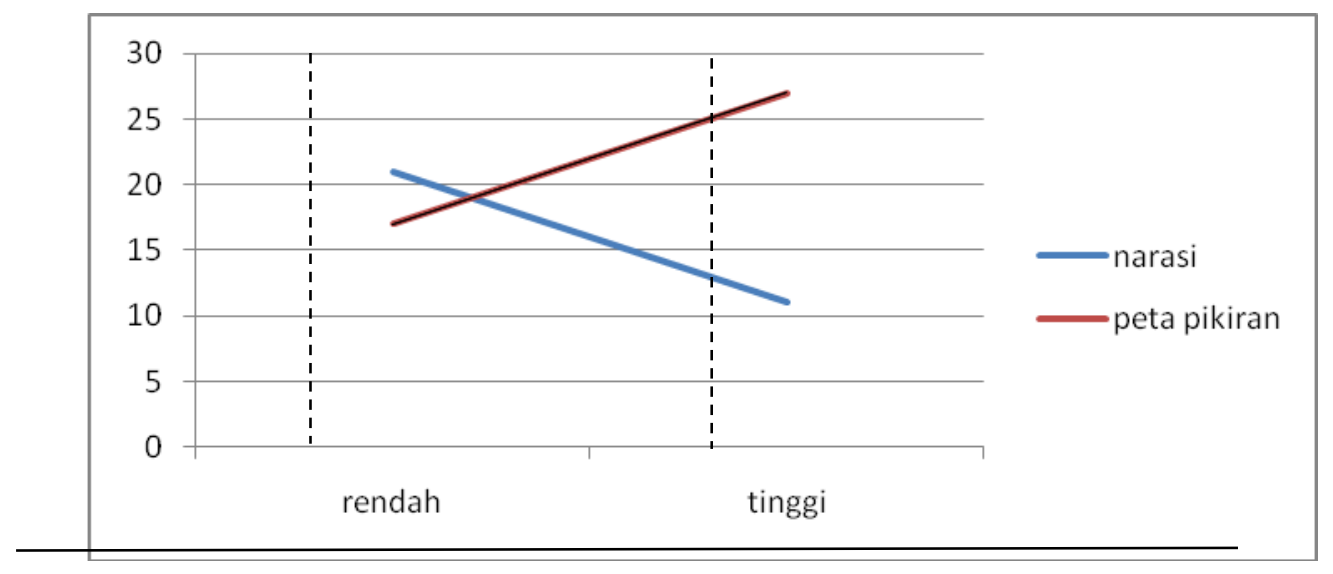

Gambar 1. Diagram interaksi antara metode pembelajaran dan komunikasi interpersonal siswa

Berdasarkan gambar tersebut dapat dilihat bahwa untuk metode pembelajaran peta pikiran, siswa yang memiliki komunikasi interpersonal tinggi menunjukkan hasil belajar yang lebih tinggi dari pada siswa yang memiliki komunikasi interpersonal rendah. Sebaliknya untuk metode pembelajaran narasi, siswa yang memiliki komunikasi interpersonal rendah memperoleh hasil belajar yang lebih tinggi dari pada siswa yang memiliki komunikasi interpersonal rendah.

\section{Pembahasan}

Data yang diperoleh dari penelitian ini ternyata menunjukkan semua hipotesis penelitian diterima yang menyatakan, (1) kelompok siswa yang menggunakan metode pembelajaran peta pikiran akan memperoleh hasil belajar biologi yang lebih tinggi dibandingkan dengan kelompok siswa yang menggunakan narasi. (2) Kelompok siswa yang memiliki kemampuan komunikasi interpersonal tinggi akan memperoleh hasil belajar biologi yang lebih tinggi dibandingkan dengan kelompok siswa yang memiliki kemampuan komunikasi interpersonal rendah. (3) Terdapat interaksi antara penggunaan metode pembelajaran peta pikiran dengan kemampuan interpersonal terhadap hasil belajar biologi siswa.

Uno (2007) mengemukakan bahwa metode pembelajaran didefinisikan sebagai cara yang digunakan guru yang dalam menjalankan fungsinya merupakan alat untuk mencapai tujuan pembelajaran. Metode pembelajaran lebih bersifat prosedural, yaitu berisi tahapan tertentu, sedangkan teknik adalah cara yang digunakan yang bersifat implementatif. Dengan perkataan lain, metode yang dipilih oleh masing-masing guru adalah sama, tetapi mereka menggunakan teknik yang berbeda.

Gagasan Ausubel tentang mata pelajaran dan struktur kognitif memiliki implikasi-implikasi penting dan langsung bagi pengelolaan kurikulum dan prosedur instruksional. Model Advance organizer dapat memperkuat struktur kognitif dan meningkatkan penyimpanan informasi baru. Penggunaan teknik meringkas catatan dengan mind map dalam pembelajaran diharapkan dapat meningkatkan hasil belajar dan kreatifitas mahasiswa. Belajar berbasis mind map didefenisikan sebagai semua perubahan pada kapabilitas dan perilaku organisme, baik secara mental maupun fisik yang diakibatkan oleh pengalaman. Terdapat banyak tambahan yang dapat diperoleh melalui penerapan mind map. Teknik meringkas catatan menggunakan mind map akan membuat ide tercurah dengan membiarkannya mengalir dari satu ide lalu memancarkannya ke ide berikutnya (Olivia, 2008).

Keuntungan lain penggunaan catatan peta pikiran yaitu membiasakan siswa untuk melatih aktivitas kreatifnya sehingga siswa dapat menciptakan suatu produk kreatif yang dapat bermanfaat bagi diri dan lingkungannya. Hal lain yang berkaitan dengan sistim limbik yaitu peranaannya sebagai pengatur emosi seperti marah, senang, lapar, haus dan sebagainya. Emosi sangat diperlukan untuk menciptakan motivasi belajar yang tinggi. Motivasi yang tinggi dapat menambah kepercayaan diri siswa, sehingga siswa tidak ragu dan malu serta mau mengembangkan potensi-potensi yang terdapat dalam dirinya terutama potensi yang berhubungan dengan kreativitas. Pemetaan pikiran adalah salah satu produk kreatif bentuk sederhana yang dapat 
dikembangkan. Dengan teknik mencatat pemetaan pikiran patut diduga bahwa kreativitas (sikap kreatif) siswa akan meningkat.

Berdasarkan hasil penelitian menunjukkan bahwa hasil belajar siswa yang memiliki komunikasi interpersonal tinggi terbukti lebih tinggi dibandingkan siswa yang memiliki komunikasi interpersonal rendah. Kesimpulan dari hasil penelitian ini juga didukung oleh pendapat Rakhmat (2004), yang mengemukakan bahwa kemampuan komunikasi setiap individu akan mempengaruhi proses, aktivitas dan hasil belajar yang bersangkutan dan membentuk kepribadiannya. Hal ini berarti dalam berbagai aktivitas sesesorang tidak terlepas dari aktivitas berkomunikasi. Komunikasi interpersonal merupakan komunikasi yang berlangsung di antara dua orang yang mempunyai hubungan yang mantap dan jelas, misalnya hubungan komunikasi guru dengan siswa maupun hubungan komunikasi siswa dengan sesama siswa. Seseorang yang memiliki komunikasi interpersonal tinggi dapat melakukan hubungan dan berbagai aktivitas termasuk dalam belajar, seperti bertanya, menjawab pertanyaan, mengajukan pendapat, menghargai ide atau pendapat orang lain dan lain sebagainya.

Komunikasi interpersonal berperan dalam mentransfer pesan/informasi dari seseorang kepada orang lain berupa ide, fakta, pemikiran serta perasaan. Oleh karena itu, komunikasi interpersonal merupakan jembatan bagi setiap individu termasuk siswa, di mana mereka dapat berbagi rasa, pengetahuan serta mempererat hubungan antara sesama individu dalam lingkungannya. Komunikasi interpersonal juga selalu menimbulkan saling pengertian atau saling mempengaruhi antara seseorang dengan orang lain.

Siswa dengan karakteristik komunikasi interpersonal tinggi adalah mereka yang mudah bergaul, aktif, optimis, bergairah, hidup semangat, memiliki sifat empati, simpati dan persuasi yang tinggi. Sedangkan karakteristik komunikasi interpersonal tertutup memiliki ciriciri yaitu sulit bergaul, senang menyendiri, acuh tak acuh, pesimis, pasif, pendiam dan sulit untuk beradaptasi dengan orang lain. Perbedaan karakteristik komunikasi interpersonal tersebut tentu saja memberikan pengaruh terhadap pencapaian hasil belajar siswa. Sehingga siswa yang memiliki komunikasi interpersonal yang tinggi dapat memperoleh hasil belajar Biologi yang lebih tinggi dibandingkan dengan siswa yang memiliki komunikasi interpersonal rendah.

Menurut Emosda (2007), sumber belajar yang digunakan merupakan sarana pendukung untuk membantu memudahkan pencapaian tujuan pembelajaran, memudahkan dalam penyajian data, informasi, dan materi pembelajaran.

Pembelajaran Biologi bukan hanya penguasaan kumpulan pengetahuan yang berupa fakta-fakta, konsep-konsep dan prinsip saja, tetapi juga merupakan suatu proses penemuan. Pembelajaran Biologi menekankan pada pemberian pengalaman. Oleh karena itu, siswa perlu di bantu untuk mengembangkan sejumlah keterampilan proses dan diharapkan dapat menjadi wahana bagi siswa untuk mempelajari dirinya (Ramdaniar, 2009).

Manurung (2011) mengemukakan bahwa salah satu faktor yang mempengaruhi hasil pembelajaran adalah media. Media pembelajaran adalah segala bentuk alat komunikasi yang dapat digunakan untuk menyampaikan informasi dari sumber ke peserta yang bertujuan merangsang mereka untuk mengikuti kegiatan pembelajaran. Media dapat juga dimanfaatkan untuk menyampaikan bagian tertentu dari kegiatan pembelajaran, memberikan penguatan maupun motivasi.

Salah satu keterampilan yang harus dimiliki oleh seorang guru adalah dapat memilih berbagai media pembelajaran dan menggunakan media yang paling sesuai agar siswa dapat dengan mudah menyerap materi pembelajaran dan mencapai tujuan-tujuan yang telah ditetapkan ( Karo-Karo, 2005). Salah satu media yang dapat digunakan adalah peta pikiran.

Karakter individu dapat di bangun dengan asumsi bahwa karakter dipengaruhi oleh lingkungan. Membangun karakter memerlukan berbagai sumber pembelajaran, sebab sumber pembelajaran yang beragam akan meningkatkan variasi dan intensitas stimulus (Menanti, 2009).

Lingkungan yang ada di sekitar siswa adalah salah satu sumber yang dapat dimanfaatkan untuk menunjang kegiatan belajar secara optimal. Apabila seorang guru mengajar dengan menggunakan lingkungan tersebut sebagai sumber belajarnya, maka hal itu akan lebih bermakna dan bernilai (Siagian, 2009). Oleh karena itu, seorang guru harus dapat menciptakan kondisi dan lingkungan yang sesuai dengan kondisi siswa untuk melaksanakan metode pembelajaran peta pikiran. 
Hutauruk (2010) mengemukakan bahwa komunikasi interpersonal adalah dalam hal menyampaikan gagasan atau pesan yang ingin disampaikan menggunakan bahasa nonverbal, bersikap terbuka, jujur, dan mendapatkan balikan dari siswa. Merubah perilaku meliputi pujian, memberikan sanksi, menjamin hubungan interpersonal yang meliputi sikap percaya diri, sportif, pengertian, menghargai, dan menerima balikan dari siswa meliputi mendengarkan dan memahami pendapat siswa.

Cara penerimaan informasi akan kurang efektif karena tidak adanya proses penguatan daya ingat, walaupun ada proses penguatan yang berupa pembuatan catatan, siswa membuat catatan dalam bentuk catatan yang monoton dan linear. Dalam hal pencatatan, seringkali individu tanpa disadari membuat catatan yang tidak efektif. Sebagian besar melakukan pencatatan secara linear, bahkan tidak sedikit pula yang membuat catatan dengan menyalin langsung seluruh informasi yang tersaji pada buku atau penjelasan lisan. Hal ini mengakibatkan hubungan antaride/informasi menjadi sangat terbatas dan spesifik, sehingga berujung pada minimnya kreativitas yang dapat dikembangkan setelahnya. Selain itu, bentuk pencatatan seperti ini juga memunculkan kesulitan untuk mengingat dan menggunakan seluruh informasi tersebut dalam belajar atau bekerja (Yovan, 2008).

Sedangkan dalam hal penyajian kembali informasi, kemampuan yang paling dibutuhkan adalah memanggil ulang (recalling) informasi yang telah dipelajari. Pemaggilan ulang merupakan kemampuan menyajikan secara tertulis atau lisan berbagai informasi dan hubungannya, dalam format yang sangat personal. Hal ini merupakan salah satu indikator pemahaman individu atas informasi yang diberikan. Dengan demikian, proses pemanggilan ulang sangat erat hubungannya dengan proses pengingatan (Yovan, 2008).

Panjaitan (2010), mengemukakan bahwa proses pembelajaran berkaitan dengan perubahan tingkah laku. Umpan balik dalam bentuk komunikasi verbal dan nonverbal memberikan penguatan bagi tingkah laku dan informasi yang kedua-duanya mempengaruhi konsep diri.

Siswa yang memiliki komunikasi interpersonal yang tinggi dapat lebih kreatif dalam mengembangkan kemampuannya bila didukung dengan metode yang sesuai seperti metode pembelajaran peta pikiran. Hal ini berkaitan dengan pemberian informasi yang di tangkap oleh siswa. Kelebihan materi pembelajaran dapat membuat siswa tidak mampu lagi menerima dan bahkan membuat siswa jenuh atau bosan dalam belajar (Panjaitan, 2010).

Siswa yang memiliki komunikas interpersonal tinggi dapat lebih kreatif dalam mengembangkan kemampuannya bila di dukung dengan metode yang sesuai seperti metode pembelajaran peta pikiran. Sedangkan siswa yang memiliki komunikasi interpersonal rendah harus lebih mendapatkan stimulasi yang lebih dari seorang guru untuk dapat meningkatkan hasil belajarnya dari pada mengembangkan kreativitasnya dalam mengembangkan catatannya, sehingga siswa tersebut cenderung lebih mudah untuk memahami pelajaran saat diajarkan dengan menggunakan metode narasi. Hal ini menunjukkan bahwa terdapat interaksi antara metode pembelajaran dan komunikasi interpersonal.

Menurut Rakhmat (2004), kemampuan komunikasi setiap individu akan mempengaruhi proses, aktivitas dan hasil belajar yang bersangkutan dan membentuk kepribadiannya. Hal ini berarti bahwa dalam proses pembelajaran di sekolah termasuk pembelajaran fisika perlu adanya komunikasi baik antara pendidik dengan peserta didik maupun komunikasi antar sesama peserta didik. Lebih lanjut menurut Max De Pree dalam Felber (2007), tidak ada usaha yang lebih penting untuk meraih keberhasilan dan hubungan antara manusia yang memuaskan daripada mempelajari seni berkomunikasi.

Rogers (1983: 17) memberi pengertian "komunikasi sebagai proses dimana para partisipan/peserta menciptakan dan saling berbagi informasi satu sama lain guna mencapai pengertian timbal balik". Dalam pengertian tersebut proses komunikasi sekurang-kurangnya harus melibatkan dua orang. Karena itu komunikasi seperti ini sering disebut komunikasi interpersonal. Di samping itu memang ada bentuk komunikasi dalam diri seseorang yang dikenal dengan komunikasi intrapersonal.

Kegiatan pembelajaran pada prakteknya di dalam kelas akan berlangsung dengan baik dan lancar jika ditunjang dengan komunikasi yang baik antara guru dengan siswa maupun antara sesama siswa. Penyampaian informasi maupun pesan bahan pelajaran juga 
dapat dikomunikasikan melalui kehadiran media pembelajaran, jika didukung dengan metode pembelajaran yang tepat. Menurut Arsyad (2002), pemilihan salah satu metode pembelajaran akan mempengaruhi jenis

Defenisi belajar menurut Bloom adalah perubahan tingkah laku yang relatif menetap sebagai hasil dari pengalaman. Secara praktis dan diasosiasikan sebagai proses memperoleh informasi . Menurut Kupferman (1981) belajar adalah proses dimana manusia dan binatang menyesuaikan tingkah lakunya sebagai hasil dari pengalaman .

Hasil belajar siswa dapat dioptimalkan dengan proses pembelajaran yang menggunakan pendekatan keseluruhan otak. Menurut Potter (2002), ketika manusia berkomunikasi dengan kata-kata, otak pada saat yang sama harus mencari, memilah, merumuskan, merapikan, mengatur, menghubungkan, dan menjadikan campuran antara gagasan-gagasan dengan kata-kata yang sudah mempunyai arti itu dapat dipahami. Pada saat yang sama, kata-kata ini dirangkai dengan gambar, symbol, citra (kesan), bunyi, dan perasaan. Sekumpulan kata yang bercampur aduk tak berangkai di dalam otak, keluar secara satu demi satu, dihubungkan oleh logika, di atur oleh tata bahasa, dan menghasilkan arti yang dapat dipahami.

Ausubel (dalam Dahar, 1988:137) mengemukakan bahwa belajar dikatakan bermakna (meaningful) jika informasi yang akan dipelajari peserta didik disusun sesuai dengan struktur kognitif yang dimiliki peserta didik sehingga peserta didik dapat mengaitkan informasi barunya dengan struktur kognitif yang dimilikinya. Ausubel (dalam Dahar, 1988 :142). Menurut Ausubel, Novak,dan Hanesian ada dua jenis belajar yaitu belajar bermakna (meaningful learning) dan belajar menghafal (rote learning).

Belajar bermakna adalah suatu proses belajar dimana informasi baru dihubungkan dengan struktur penertian yang sudah dipunyai seseorang yang sedang belajar .Belajar bermakma terjadi bila pelajar mencoba menghubungkan fenomena baru dengan konsep yang telah ada sebelumnya. Bila konsep yang cocok dengan fenomena baru itu belum ada maka informasi baru tersebut harus dipelajari secara menghafal. Belajar menghafal ini perlu bila seseoarang memperoleh informasi baru dalam dunia pengetahuan yang sama sekali tidak berhubungan dengan apa yang ia ketahui sebelumnya.
Menurut Ausubel belajar dapat diklasifikasikan kedalam dua dimensi. Dimensi pertama berhubungan dengan cara informasi atau materi pelajaran itu disajikan kepada siswa melalui penerimaan atau penemuan. Selanjutnya dimensi kedua menyangkut bagaimana siswa dapat mengaitkan informasi itu pada struktur kognitif yang telah ada. Jika siswa hanya mencoba menghafalkan informasi baru itu tanpa menghubungkan dengan struktur kognitifnya, maka terjadilah belajar dengan hafalan. Sebaliknya jika siswa menghubungkan atau mengaitkan informasi baru itu dengan struktur kognitifnya maka yang terjadi adalah belajar bermakna.

Keberhasilan siswa dalam belajar dapat dipengaruhi oleh banyak faktor salah satunya komunikasi interpersonal siswa. Siswa dengan karakteristik komunikasi interpersonal tinggi adalah mereka yang mudah bergaul, aktif, optimis, bergairah, hidup semangat, memiliki sifat empati, simpati dan persuasi yang tinggi. Sedangkan karakteristik komunikasi interpersonal rendah memiliki ciri-ciri yaitu sulit bergaul, senang menyendiri, acuh tak acuh, pesimis, pasif, pendiam dan sulit untuk beradaptasi dengan orang lain. Oleh karena perbedaan karakteristik komunikasi interpersonal ini akan memberikan pengaruh terhadap pencapaian hasil belajar siswa.

\section{PENUTUP \\ Simpulan}

Berdasarkan hasil penelitian dan pembahasan, maka simpulan yang dapat diambil dari penelitian ini adalah:

1. Metode pembelajaran peta pikiran lebih efektif digunakan dari pada metode pembelajaran narasi dalam meningkatkan hasil belajar Biologi.

2. Siswa yang memiliki komunikasi interpersonal tinggi memperoleh hasil belajar Biologi lebih tinggi dari pada siswa yang memiliki komunikasi interpersonal rendah.

3. Terdapat interaksi antara metode pembelajaran dan komunikasi interpersonal yang dimiliki siswa. Sebagaimana uji lanjut (uji Scheffe) yang menunjukkan bahwa :

a. Rata-rata skor hasil belajar Biologi siswa yang diajar dengan menggunakan metode pembelajaran peta pikiran dan memiliki komunikasi interpersonal tinggi lebih tinggi dibanding siswa yang diajar dengan metode pembelajaran narasi. 
b. Rata-rata skor hasil belajar Biologi siswa yang diajar dengan metode pembelajaran narasi dan memiliki kepribadian komunikasi interpersonal rendah lebih tinggi dibanding siswa yang diajar dengan metode pembelajaran peta pikiran.

\section{Saran}

Sebagai tindak lanjut dari hasil penelitian, kesimpulan yang telah dikemukan, maka diajukan beberapa saran sebagai berikut:

1. Kepada para siswa diharapkan untuk lebih aktif dan semangat dalam belajar, dan disarankan untuk mampu berkomunikasi secara interpersonal dengan baik dan terbuka dalam kegiatan belajar, tidak malu bertanya maupun mengajukan pendapat tentang apa yang dipelajari di dalam kelas, mampu untuk beradaptasi dengan orang lain maupun dengan kegiatan atau aktivitas yang berlangsung selama proses pembelajaran, lebih menumbuhkan sikap optimis maupun sifat empati, simpati dan persuasi yang tinggi.

2. Kepada guru, hendaknya dapat merancang dan mengembangkan sutau metode pembelajaran yang dapat memberikan kebebasan siswa untuk aktif belajar, menemukan, mencari tahu dan berbuat sehingga dapat membantu siswa untuk memperoleh pemahaman yang lebih mendalam tentang materi yang dipelajari

3. Kepada peneliti selanjutnya diharapkan untuk dapat melakukan penelitian lebih lanjut dengan topik atau permasalahan yang sama sehingga diperoleh hasil penelitian yang lebih menyeluruh. Hal ini penting agar hasil penelitian ini bermanfaat sebagai penyeimbang teori maupun sebagai reformasi terhadap dunia pendidikan khususnya dalam penggunaan metode dan media pembelajaran yang tepat di dalam kelas.

\section{DAFTAR PUSTAKA}

Abdurrahman, M. 2003. Pendidikan Bagi Anak Berkesulitan Belajar. Jakarta: Rineka Cipta

Ausubel, D.P. 1963. The Psychology of Meaningful Verbal Learning. New York: Holt, Rinehart and Winston

Buzan, T. 2008. Buku Pintar Mind Map. Jakarta: PT. Gramedia Pustaka Utama
Buzan, T. 2007. Buku Pintar Mind Map untuk Anak. Jakarta: PT. Gramedia Pustaka Utama

DePorter, B. dan Mike, H. 2000. Quantum Learning: Membiasakan Belajar Nyaman dan Menyenangkan. Bandung : Kaifa

DePorter, B., Reardon, M. dan Nouri, S.S. 2002. Quantum Teaching: Mempraktekkan Quantum Learning di Ruang-ruang Kelas. Bandung : Kaifa

Dick, W. and Carey, L. 2005. The Systematic Design of Instruction ( 2 nd Ed ). Glecview, Illinois: Scot Foresman and Company

Djamarah, S.B. dan Zain, A. 2002. Strategi Belajar Mengajar. Jakarta: Rineka Cipta

Emosda. Faktor Guru dalam Aktifitas Pembelajaran di Kelas. Tabularasa Vol. 07 No. 04 No. 2 Desember 2007. Jurnal Pendidikan Pascasarjana UNIMED

Gagne, R.M. and Briggs, L.J. 1979. Principles of Instruction Design. New York: Holt, Rinehart and Wiston

Hamalik, O. 2004. Proses Belajar Mengajar. Jakarta: Bumi Aksara

Hamid, A. 2009. Teori Belajar dan Pembelajaran. Medan: PPS Unimed

Herlina. 2007. Pengaruh Pengelolaan Kelas Terhadap Hasil Belajar Biologi Siswa. http//idb4.wikispaces.com/file/view/ss40 04.pdf

Hutauruk, G.M. Hubungan Motivasi Kerja, Kecerdasan Emosional, dan Komunikasi Interpersonal dengan Efektifitas Manajemen Kelas Guru SMK di Kabupaten Simalungun. Tabularasa Vol. 07 No. 1 Juni 2010. Jurnal Pendidikan Pasca sarjana Unimed

Joyce, B., Weil, M., and Calhoun, E. 2009. Models of Teaching. Jakarta: Pustaka Pelajar

Karo-Karo, D. Pengaruh Menggunakan Media dan Kecerdasan Emosional Mahasiswa Terhadap Hasil Belajar IPA. Jurnal Penelitian Bidang Pendidikan Vol. 12 No. 1 Bulan/Tahun: September 2005. Lembaga Penelitian UNIMED

Komala, L. 2009. Ilmu Komunikasi, Persfektif, Proses, dan Konteks. Bandung: Widya Padjadjaran

Mahmuddin. 2009. Pembelajaran Berbasis Peta Pikiran (Mind Mapping). http://astutiamin.wordpress.com. Diakses April 2011. 
Merrill. M.D. 1991. Construktivism and Instructional Design. New Jersey: Educational Technology

Miarso Y. 2005. Menyemai Benih Teknologi Pendidikan. Jakarta: Kencana

Muhammad, A. 2007. Komunikasi Organisasi. Jakarta: Bumi Aksara

Mulyana, D. 2007. Ilmu Komunikasi. Bandung: Rosdakarya

Nasution, S. 2009. Berbagai Pendekatan dalam Proses Belajar dan Mengajar. Jakarta: Bumi Aksara

Olivia, F. 2008. Gembira Belajar dengan Mind Mapping Bantu Anak Menguasai Senjata Para Jenius untuk Melejitkan Prestasi di Sekolah. Jakarta: Elex Media Komputindo dan Kompas Gramedia

Panjaitan, K. 2010. Merancang Butir Soal dan Instrumen untuk Penelitian. Gorontalo: Nurul Jannah

Panjaitan, K. Sistem Komunikasi Interpersonal dalam Pendidikan. Jurnal Teknologi Pendidikan. Vol. 2 No. 1 April 2009. Prodi Teknologi Pendidikan Pascasarjana UNIMED

Panjaitan, K. Persepsi Interpersonal dan Konsep Diri dan Implikasinya dalamPendidikan. Jurnal Teknologi Pendidikan Vol. 3 No. 1 April 2010. Prodi Teknologi Pendidikan Pascasarjana UNIMED

Reigeluth, C.M. 1983. Instrucional Design Theories and Models: An Overview of
Their Current Status. New Jersey: Publisher Hilsdale

Romizowski, A.Z. 1981. Designing Instructional System. New York: Nichol Publishing Company

Sardiman. 2009. Interaksi dan Motivasi Belajar Mengajar. Jakarta: PT. Raja Grafindo Persada

Sitorus, R., Mardianto dan Mahidin. 2005. Prinsip-prinsip dan Teknik Pembelajaran Siswa. Fakultas Tarbiyah IAIN Sumatera Utara.

Sitompul, E.S. 2010. Pengaruh Strategi Pembelajaran dan Komunikasi Interpersonal Terhadap Hasil Belajar IPS Siswa SMPN 37 Medan. Tesis tidak diterbitkan. Medan: Program Pascasarjana UNIMED.

Slameto. 2003. Belajar dan Faktor-faktor yang Mempengaruhinya. Jakarta: Rineka Cipta

Sugiarto. 2004. Mengoptimalkan Daya Kerja Otak dengan Berpikir Holistik dan Kreatif. Jakarta: Gramedia Pustaka Utama

Suparman, M.A. 2001. Desain Instruksional. Jakarta: PAU-PPAI-UT

Syah, M. 2008. Psikologi Pendidikan dengan Pendekatan Baru. Bandung: PT. Remaja Rosdakarya

Uno, H.B. (2007). Model Pembelajaran: Menciptakan Proses Belajar Mengajar yang Kreatif dan Efektif. Jakarta: Bumi Aksara 